\title{
Motivation and its Basic Theories
}

\author{
Ivan Uher ${ }^{1 *}$, Jaroslaw Cholewa ${ }^{2}$, Marcin Kunicki ${ }^{3}$, Iveta Cimbolaková ${ }^{3}$ and David Kaško ${ }^{4}$ \\ ${ }^{1}$ Institute of Physical Education and Sport, PJ Safarik University, Slovakia, Poland \\ ${ }^{2}$ Department of Physical Education, J Kukuczka Academy of Physical Education, Katowice, Poland \\ ${ }^{3}$ Department of Physical Education, State Higher Vocational School, Raciborz, Poland \\ ${ }^{4}$ Faculty of Sports, University of Prešov, Prešov, Slovakia, Poland
}

Submission: January 23, 2018; Published: February 02, 2018

*Corresponding author: Ivan Uher, Institute of Physical Education and Sport, P J Safarik University, Slovakia, Poland, Tel: (421)915316532;

Email: ivan.uher57@gmail.com

\begin{abstract}
The course that behavior takes is a function of the person's essential needs, goals, wants, personality etc. There is a general consensus that motivation is goal directed, outlines the achievement and pursuit of goals and that motivation in environmentally dependent. Motivation causes the initiation, direction, intensity and persistence of behavior. In that respect motivation involve the biological, emotional, social, and cognitive forces that activate behavior. In our review, we look into goal-directed behavior aspect of motivation. In that respect, there are two basic approaches to explaining motivation as goal directed behavior. Achievement motivation (AM) theory and the attribution theory (AT). We will examine achievement motivation and attribution motivation apart, mainly because their theoretical constructs are dissimilar. We can conclude that motivation is multifactorial in nature and heading to the maintenance of a state of physiological and psychological homeostasis.
\end{abstract}

Keywords: Achievement theory; Attribution theory; Behavior; Personality; Goal

\section{Introduction}

\section{Achievement Motivation Theory}

We can characterize motivation as a basic force behind all of our pursuit. We recognize number of different forms of motivations, extrinsic, intrinsic, physiological, achievement motivation etc. Particularly, achievement motivation has been conceptualized in many different ways. We are aware of the reality, that not everyone approaches an achievement situation with the same vehemence. Especially, achievement situation in one in which someone expects that his action is going to be evaluated. Achievement motivation we can characterize as the need for success or the attainment of excellence [1-3]. In that context, we will focus on a simplified version of this model. This model proposes that two factors determine achievement, motive to bring in success, and the motive to avoid failure. The motive to achieve success presupposes to represent an intrinsic motivation. It is grossly speaking equivalent to the notion of self-confidence, self-efficacy, and personal competence. People possessing this quality are more likely than those who are not to enter into a situation in which they will be evaluated by others. The second factor that determined whether a person will engage in competitive state is the motive to avoid failing. This factor may suggest subject's personality disposition for anxiety. A highly distress person is prone to avoid competitive situation, rivalry than one who is low in that aspect. A second eminent component of this model is the likelihood of success, and the incentive value of success, notion about an achievement situation, thus incentive value of success may amplify as the probability of success decreases.

This speculation thus makes sense as the one should place more value upon succeeding at a laborious assignment than an easy one. In that respect, the risk-taking behavior can be important to the model of achievement motivation. We have to mention that this behavior is more favorable among male than female. Not edge out that some people who are low in motivation to achieve success and high in motivation to avoid failure still enter into achievement situations. Take into consideration, that extrinsic motivation might make the difference that comes in many forms, often in terms of praise, money, importance, usefulness, costs, and so forth. Taking into account that motive to achieve success and the motive to avoid failure are personality variables. On the other hand, the probability of success and incentive value of success represents situational variables. Nevertheless, we have to consider perceived contingence that take into account the fact that many achievement situations have implications for future goals and aspirations [4]. That means, person recognizes that his pursuit affects opportunity to reach his ultimate goal. Simply, performance in any achievement related activity is a function of both immediate and future intended success and failure. 
Thus, someone who feels that his future opportunities depend upon present performance will reveal a greater desire to achieve, that is future success is tied to present achievement [5]. However, is very difficult to predict success based on personality alone. It is true that a number of studies have found that higher levels of achievements are associated with superior performance [6-8]. Some studies found relationship between performance and achievement, but only in the early stages of learning, but thereafter, differences in achievement disappear $[9,10]$. Subjects initially high in achievement become bored with the relatively easy task and their motivation decreases. Conversely, subjects initially low in achievement are motivated by their unexpected success, and hence achievement motivation increases. Ryan et al. [11] in his study found that in a noncompetitive situation, low motivated subjects perform better than high achievement subjects, but in a competitive situation the opposite is true. Authors concluded that anxious individuals tend to do well in a relaxed, nonthreatening environment, but not in a pressure paced competitive situation.

Competition enhance the performance of high achievement subjects while if cause a decrement in the performance of low achievement subjects. Despite of that, it seems unlikely that performance can be predicted solely on the basis of achievement model. However, achievement model can be real value of measuring achievement in predicting long term patterns of motivation, not in predicting success in a specific event. Gebauer [12] coming to recognize that the critical factor that differentiates high and low achievement individuals is self-confidence and self-esteem. Individuals lacking in self-confidence tend to avoid social evaluation situations, while those high in self-confidence enthusiastically engage in achievement situations. We can meditate that achievement motivation is closely linked to the concepts of self-confidence and self-esteem. Self-confidence seems to be synonymous with concepts of personal competence and self-efficacy [13]. Bandura [14] has proposed a model of selfefficacy that states that self-efficacy is enhanced by successful performance, vicarious experience, verbal persuasion, and emotional arousal. The most important of these four factors is successful performance. Successful performance raises expectation for future success. Failure lowers these expectations. Once strong feeling of self-efficacy developed through repeated success, occasional failures will be of small consequence. In that respect assist subject in successfully performing the tusk can will be crucial. The subject is not allowed to fail.

As a result of repeated success, strong feelings of selfefficacy develop. Bandura [15] predicts that self-efficacy leads to increased performance. This theory suggests that achievement can be enhanced through repeated experience of success. In that respect, we should help subject develop his/her motivation by making sure he is not confronted with repeated failure. When the importance of "winning" is de-emphasized and success viewed in terms of effort and improvement, situation can be a positive experience for partaker. We did not discuss ego involvement that demonstrates superior abilities. Where, ego involved individuals are driven to succeed to outperform others, and their feelings of success depend on maintaining selfworth and avoiding failure. This setting brings about different goals, conceptions of ability, and responses to difficulty. They also promote different patterns of information seeking. They are more interested in information about social comparisons, assessing their ability relative to others. In this respect, we can conclude that positive reinforcement and avoidance of failure a delicate balance of both approach and avoidance motivation may lead to a more well-rounded successful outcome. One of the weaknesses of this model is that it does not provide an account of the processes responsible for the link between achievement goals and performance.

\section{Attribution Theory of Motivation}

The key element in attribution theory is perception. When person is asked, to what do you attribute your success? He is being asked for his perception. The fact that his perception of why he is successful may be completely erroneous is beside the point. Attribution theory is a cognitive approach to motivation. One of the primary assumptions of attribution theory is that people will interpret their environment in such a way as to maintain a positive self-image. Intention of every human being is to explain his or her own actions in terms of their perceived causes. Thus, we can view attribution theory as a layman's theory of perceived motivation. Most of the research Harvey et al. [16] that uses attribution theory deals with understanding when and why people select certain categories of attribution. The attributions that subject's select reveal his motivational structure. Furthermore, helping subject to change his, perception can have a significant impact on his motivation to achieve. For this reason, achievement and attribution theory are very closely related [17]. According to Graham [18] outcomes are attributed to the person (personal force) or the environment (environment force) or to both. Effective personal force is composed of the factors ability and trying (effort). Trying in turn is composed of the factors intention and exertion. Intention is the qualitative component and represents what the person is trying to do, while exertion is the qualitative component and represents how much effort is expended.

Where ability and the environment force factor of task difficulty interact to yield, a separate dimension referred to as can or cannot. Nevertheless, highly unstable factor of luck also enters into many attribution situations. Luck is a variable environmental factor that can favorably or unfavorably change an outcome in an unsystematic way. However, we must take into consideration that what one person calls luck another person may call ability. All of above mentioned factors (trying, ability, task difficulty, and luck) combined result in a behavioral outcome, to which and individual attributes a cause. Therefore, relationship between the personal and environmental components of causation can be additive. Persons, who exhibit external control, tend to attribute their outcome to outside forces such as fate, chance, and other 
people. Those who exhibit internal control tend to believe their behaviors influence outcomes. Anyway, both ability and effort are internal or personal in nature, ability is relatively unchanging or stable, while effort is constantly changing or unstable. Another category for classifying attribution is controllability. A controllable attribution is one in which the persons' perception is under his or her control. An uncontrollable attribution is not. We have to recognize that the kinds of attribution people make are based upon a socialization process.

Socialization plays an important part in the emphasis that we place on attributions. Attributions depend on what we learn to value. Further, we can predict future expectations about performance based on the kinds of attributions person gives for his present performance. If the person attributes a failure to bad luck, he or she is saying that things may be different next time. But if the failure is attributed to a lack of ability, the person is saying that the result will be the same next time. So much as, in need achievement situations, some people act as if events are out of their control, that failure is inevitable. The subject who displays these characteristics in competitive situations is suffering from learned helplessness [19]. Person who show a deterioration of performance under the threat of failure tend to attribute his failure to stable factor, such as lack of ability. Those who show enhanced performance under the threat of failure tend to choose unstable factors such as luck of lack of effort. Therefore, helping person to change his attribution may be more beneficial than merely manipulating success. This does not mean that experiencing success is not important. It is. But performance and self-efficacy can also be enhanced by helping person to make confidence building or protecting attributions.

People are assumed to follow logic when they make attributions to behavioral outcome. However, evidence suggests that people are not always entirely logical in making causal attribution for their behavior. Instead of making logical attributions, they often make blatantly self-serving ones. In this regard, a person might attribute success to internal causes and failure to external causes [20]. However, Carron [21] noted that subjects tended to view lack of effort as an external attribution rather than an internal one. Baumeister [22] suggesting that the attribution process, is probably neither purely logical nor purely illogical (self-serving). Rather, the disposition to use a self-serving strategy is within each individual to some degree. Some people will rarely use it, others may find it comforting to reject personal responsibility for outcome in order to protect own ego. Therefore, we should learn to accept responsibility for our own outcomes, but not at the expense of our own selfconfidence. It is appealing to assume that extrinsic reward can enhance motivation. Research on attribution theory [23] has led to the conclusion that extrinsic rewards can damage our intrinsic desire to compete.

Fiske et al. [24] argue that it must be due to the added incentive to extrinsic motivation. In other words, intrinsic motivation and extrinsic motivation combine to create need achievement. More specifically it has been argued that the relationship between intrinsic and extrinsic motivation is multiplicative, not additive. That is, extrinsic rewards can either add to or detract from intrinsic motivation. Berliner, Calfee [25] theorizing that extrinsic rewards can affect intrinsic motivation in two ways. The first, when person come to perceive that his behavior is controlled by external forces, he responds with decreased level of intrinsic motivation. The second, effect of extrinsic motivation is informational in nature and results in an increase in intrinsic motivation. Not but that, $[26,27]$ research suggests that an internal locus of control is better than an external locus of control. In completion, LeUnes [28] demonstrated that internals demonstrate less performance disruption under stress than externals and are better able to use task centered coping behaviors.

\section{Conclusion}

In our review two basic theories of motivation were discussed, model based upon the motive to succeed and the motive to avoid failure. In conclusion, we make attempt to bring together all above mentioned principles and applications. People's motive to achieve and their fear of failure are the primary factors determining whether they will approach or avoid and achievement situation. The probability of success and incentive value of success is factors that influence subject achievement. Person who is low in motive to achieve success and high in motivation to avoid failure should be guided into situation of high or low probability of success. If future opportunity depends upon present performance, the subject's achievement can be either enhance or diminished. It will be enhanced if the motive to succeed is greater than the motive to avoid failure. The real value of measuring achievement is in predicting long-term patterns of motivation, not in predicting success in a specific event. Also, self-efficacy, and hence achievement motivation, can be developed through execution of mastery.

Attributions that person select to explain his outcomes reveal much about our motivational structures. An internal locus of control is preferred to an external locus of control. The kinds of attributions that person makes for success and failure are closely associated with our emotions. According to the co variation principle, outcomes that agree with the performance of other usually result in external attributions, while outcomes that disagree usually result in internal attributions. We are tending to give stable attributions in response to unexpected outcomes. Attributing failure to an internal-stable cause is potentially damaging to person self-esteem. More so, attributing success to an internal-stable cause such as ability is good for a persons' self-esteem. Many times, we are not completely logical in our attributions, therefore often engaging in illogical or egoenhancing strategies to explain events. Base on above mention we can conclude, that development of a persons' motivation is ultimate goal.

In that context, intrinsic motivation such as (interest, challenge, learning, meaning, purpose etc.) extrinsic (money, 
fame, awards, praise, status, opportunities, social aspect, deadlines, bribes, threats, commitments etc.) personal (power, harmony, achievement, public recognition, security, pleasure, knowledge, authenticity etc.) and interpersonal (copying, rebellion, competition, collaboration, encouragement etc.) motivations are always additive in the nature. Whether motivation impulses are taken directly from the environment or imposed by individuals, there is always a choice to be made, be it conscious or unconscious. Nevertheless, no one can make a subject do anything, a person's perception of reality forms person's motivation. Despite the extensive research on motivation, true human motivation, motivational drive will always be multi factorial in nature. The question remains, how do different types of motivation interact to describe behavior? As long as there is a liberty of choice, it is highly unlikely that any theory of motivation will work for all people. On the conclusion, we believe that there is no master theory that can be applied to every person or situation and as such, the only way to truly understand and motivate person is to simply approach and treat person individually.

\section{References}

1. Atkinson JW (1957) Motivation determinants of risk taking behavior Psychological Review 64(6): 359-372.

2. Eccles JS, Wigfield A, Midgley C, Reuman D, MacIver D, et al. (1993) Are traditional middle grades scholls undrmining the academic motivation of early adolescents?. Elementary School J 93(5): 552-574.

3. Nicholls JG (1984) Achievement motivation: conceptions of ability, subjective experience, task choice, and performance. Psychological review 91(3): 328-346.

4. Weiner B (1972a) Attribution theory, achievement motivation and the educational process. Review of Educational Research 42(2): 203-215.

5. Weinberg RS, Gould D (2007) Foundations of sport and exercise psychology. ( $4^{\text {th }}$ edn) Human Kinetics, USA.

6. Bagozzi RP (1992) The self-regulation of attitudes, intentions and behavior. Social Psychology Quarterly 55(2): 178-204.

7. Vallerand RJ, Rousseau FL (2001) Intrinsic and extrinsic motivation in sport and exercise. A review using the hierarchical model of intrinsic and extrinsic motivation. In: RN Singer, HA Hausenblas, CM Janelle Handbook of Sport Psychology ( $2^{\text {th }}$ edn). Pub John Wiley and Sons, USA.

8. De la Pena D (2004) Scripture and Sport Psychology. Pub Tyndale House publishers Illinois pp. 152.

9. Harackiewicz JM, Hulleman CHH (2010) The importance of Interest: The role of achievement Goals and Task Values in Promoting the Development of Interest. Social and Personality Psychology Compasss $4(1): 42-52$
10. Elliot AJ, Mc Gregor H (2001) A 2x2 achievement goal framework. Journal of Personal and Social Psychology 80(3): 501-519.

11. Ryan E, Dean E, Lakie WL (1965) Competitive and noncompetitive performance in relation to achievement motive and manifest anxiety. Journal of Personality and Social Psychology 1(4): 342-345.

12. Gebauer JE (2008) The relationship between self-esteem and psychological health: Dissertation thesis. Pub Pro Quest pp. 221.

13. Pajares F (1997) Curent directions in self-efficacy research. In: M Maehr, PR Pintrich (Edn): Advances in motivation and achievement, Greenwich JAI press 10: 1-49.

14. Bandura A (1977a) Self-efficacy: Toward a unifying theory of behavioral change. Psychological Review 84(2): 191-215.

15. Bandura A (1978b) Reflections on self-efficacy. Advances in Behavioral Research and Therapy 1(4): 237-269.

16. Harvey JH, Ickes W, Kidd FR (1978) New Directions in Attribution Research. Pub Lawrence Erlbaum Association 2: 420.

17. Weiner B (1985b) An attributional Theory of Achievement Motivation and Emotionn: Psychological Review. American Psychological Association, USA, 92(4): 548-573.

18. Graham S (1991) A review of attribution theory in achievement context. Educational Psychology Review 3(1): 5-39.

19. Peterson CH, Maier SF, Seligman P (1993) Learned Helplessness: A Theory for the Age of Personal Control. Pub Oxford University Press, USA.

20. Fontaine G (1975) Causal attribution in simulated versus real situations: When are people logical, and when are they not?. Journal of Personality and Social Psychology 32(6): 1021-1029.

21. Carron AV (2008) Social Psychology of Sport: An experimental Approach. Virginia university publications pp. 101.

22. Baumeister FR, Bushman BJ (2009) Social Psychology and Human Nature $\left(2^{\text {th }}\right.$ edn). Wadsworth publication pp. 429.

23. Forsterling F (2001) Attribution: An introduction to Theories, Research and Applications. Psychology press, UK.

24. Fiske ST, Gilbert TD, Lindzey G (2010) Handbook of social psychology ( $5^{\text {th }}$ edn). Wiley Publishers 1: 268-316.

25. Berliner CD, Calfee CR (2004) Handbook of Educational Psychology. Routledge Publishers Company, UK.

26. Phillips JM, Gully SM (1997) Role of goal orientation, ability, need for achievement, and locus of control in the self-efficacy and goal-setting process. Journal of Applied Psych 82(5): 792-802.

27. Lefcourt MH (1984) Research with the locus of control construct: Extensions and Limitations. Academic press 3: 407.

28. LeUnes AD (2008) Sport Psychology ( $4^{\text {th }}$ edn). Pub Psychology press, Pennsylvania State University, USA. 
This work is licensed under Creative Commons Attribution 4.0 Licens

DOI: 10.19080/JPFMTS.2018.01.555572

\section{Your next submission with Juniper Publishers} will reach you the below assets

- Quality Editorial service

- Swift Peer Review

- Reprints availability

- E-prints Service

- Manuscript Podcast for convenient understanding

- Global attainment for your research

- Manuscript accessibility in different formats ( Pdf, E-pub, Full Text, Audio)

- Unceasing customer service

Track the below URL for one-step submission https://juniperpublishers.com/online-submission.php 